\title{
Critical analysis of the regulations regarding the disposal of medication waste
}

\author{
Natalia Bellan",*, Terezinha de Jesus Andreoli Pinto', Telma Mary Kaneko', \\ Lauro Domingos Moretto ${ }^{2}$, Nelson dos Santos Junior ${ }^{3}$
}

\begin{abstract}
${ }^{1}$ Department of Pharmacy of the Pharmaceutical Science School, University of São Paulo, ${ }^{2}$ Departament of Technology, Pharmaceutical Science School, University of São Paulo, ${ }^{3}$ U.S. Pharmacopeia Brazil
\end{abstract}

\begin{abstract}
Expired or unused medication at people's homes is normally disposed of in normal garbage, sewage system or, in certain cases, returned to the public health system. There is still no specific legislation regarding this leftover medication to regulate and orient the handling and correct disposal of medication waste. However, there is defined regulation regarding health services' solid waste. This article has the objective of discussing management models for the disposal of medication waste and the recommendations made by pertinent national and international legislation. By means of literature reviews, the management structure for medication waste of international legislation and the regulations regarding the environment, as well as the national legislation for the solid waste from health services was analyzed. Through the analysis it was possible to present better clarifications as to the possible impacts to the environment, to the public's health and alternatives in order to obtain the efficient disposal of medication, reducing and/ or avoiding sanitary risk, guaranteeing the quality and safety of public health.
\end{abstract}

Uniterms: Medications/disposal. Medications/solid waste/disposal. Sanitary risk. Environmental contamination. National Solid Waste Policy.

As sobras de medicamentos oriundas do desuso ou da expiração do prazo de validade que constam nos domicílios da população, normalmente, são destinadas diretamente para o lixo comum, rede de esgoto ou, em alguns casos, devolvidas para a rede pública. Sobre essas sobras, ainda não há legislação específica que regulamenta e orienta sobre a manipulação e destinação correta do descarte dos resíduos de medicamentos. Entretanto, sobre os resíduos sólidos de serviços de saúde já se possui regulamentações definidas. O presente artigo tem como objetivo discutir modelos de gestão de descarte de resíduos de medicamentos e as recomendações de legislações internacionais e nacionais pertinentes. Por meio de revisão de literatura, analisou-se a estrutura do gerenciamento de resíduos para medicamentos de legislação internacional e as regulamentações relacionadas ao meio ambiente, assim como a legislação nacional de resíduos sólidos de serviços de saúde. Com a análise foi possível apresentar melhores esclarecimentos quanto aos possíveis impactos ao meio ambiente, à saúde da população e alternativas para se obter gestão eficaz de descarte de medicamentos, reduzindo e/ou evitando o risco sanitário, garantindo qualidade e segurança da saúde pública.

Unitermos: Medicamentos/descarte. Medicamentos/resíduos sólidos/descarte. Risco sanitário. Contaminação ambiental. Política Nacional de Resíduos Sólidos.

\section{INTRODUCTION}

Towards the end of the $20^{\text {th }}$ century, a growing concern of society with environmental issues was observed,

\footnotetext{
*Correspondence: N. Bellan. Departamento de Farmácia, Faculdade de Ciências Farmacêuticas - USP. Av. Prof. Lineu Prestes nº 580 - Bloco 13 inferior - 05508-900 - São Paulo - SP, Brasil. E-mail: nataliabellan@usp.br
}

engaging in the reformulation of alternatives aiming at a balance between economic development and environmental conservation. This objective was especially dealt with by the so-called sustainable development or ecodevelopment (Milaré, 2005).

Concerns with sustainable production have not merely been emotional or sterile. Among the many initiatives made in reference to the issue, we must mention the 
international regulation drafted and proposed by ISO - International Organization for Standardization, summarized in the ISO 14.000 series. This international organization, with headquarters in Geneva, has been acting within its specific corporate purposes since 1947. Over the last few years, it has drafted norms to ensure the quality of industrial products, the ISO 9.000 series. The norms in the ISO 14.000 series aim at protecting, in an environmental quality aspect, not only the products, but the productive processes as well (Milaré, 2005).

In Brazil, the first indications of concerns with the environment are found in the Portuguese legislation, which was in effect until the Civil Code was created in 1916 (Junior et al., 2005).

The greatest movements regarding the subject were due to the international conference on the main environmental problems, proposed by Sweden to the UN (Junior et al., 2005).

In 1972, in the city of Stockholm, the UN held the United Nations Conference on the Human Environment, with the participation of 113 countries. From this conference, the creation of the United Nations Environmental Program - UNEP and the inquiries made by third world countries, led by Brazil, regarding the attitude of rich countries are noteworthy (Junior et al., 2005).

It is also necessary to mention the importance of the approval of Law 6.151, of 1974, which deals with the National Development Plan - NDP to be executed from 1975 to 1979, which incorporates an environmental policy concern. Since the country's first environmental regulatory milestone was Law 6.938, of 1981, which deals with the National Environmental Policy, its purposes and formulation and application mechanisms, and other provisions, and institutes the National Environmental System (SISNAMA) (Junior et al., 2005).

The second milestone coincides with the publication of Law 7.347, of 1985, which deals with matters such as public civil lawsuits as a specific procedural instrument to defend the environment, transforming it into a legal matter.

The third milestone came with the Federal Constitution of 1988, incorporating the environmental issue.

The fourth milestone is represented by Law 9.605, of 1998, which deals with legal and administrative sanctions deriving from conduct and activities that harm the environment, and includes other provisions; known as the "Environmental Crimes Law"

After World War II, precisely in the 60's, a practical awareness begins to take form in the use of natural resources in an adequate manner; raw materials, energy and water, among other resources provided by nature, which become rarer and more expensive. The environmental degradation processes, in various forms, begin to spread. New crises, which are more serious and global, take shape on the horizon for a society that, without embargo, insists on closing its eyes and ears to reality. Heavy clouds pile up over the fate of the planet. There is a limit for growth as well as a limit for inconsistency. It was then the cry and the light from Stockholm that became present, for good. From then on, environmental awareness has been extending itself and becoming more robust (Milaré, 2005).

Thus, Environmental Law is born, which can be interpreted as a set of concepts and regulation norms that aim at human direct or indirect action to the environment, which may damage the environment's health globally, with the objective of maintaining sustainability for the generations of today and tomorrow (Milaré, 2005).

There is currently a discussion regarding the problem of solid waste generation, which involves all areas of society's activities, such as techno-scientific, public administration, public health, due to the interrelationship between the environment and quality of life.

The monitoring of residual pharmaceuticals in the environment has gained a lot of interest from society, which also has its share of responsibility as to environmental conservation. This concern is justified because if the medications are used and/or improperly discarded into the environment through the water, soil and air, may become a polluting agent for nature and public health.

The main contributor for this type of contaminant in superficial water is the release of untreated sewage, considering that there is a huge sanitation infrastructure deficit in many locations. Only $20.2 \%$ of Brazilian municipalities collect and treat domestic sewage, $32 \%$ only have the collection service and in $47.8 \%$ of the municipalities, the sewage isn't collected and is released directly into the water. The situation is a little better in the Southeastern region, but still, only $33.1 \%$ of the municipalities have a collection and sewage treatment services, $59.8 \%$ only collect and $7.1 \%$ of the municipalities don't even have a collection service (Melo et al., 2005).

The main point of entry of pharmaceutical waste is the release of domestic sewage, treated or not, into water systems. However, the pharmaceutical industry effluents, rural effluents, the presence of pharmaceuticals in animal manure used for the fertilizing of soil and the improper disposal of pharmaceuticals after they expire must also be taken into consideration (Melo et al., 2005; Eickhoff et al., 2009).

Another relevant aspect are the leftover medications that originate from the dispensing of excessive medication for the treatment, the free samples distributed by the pharmaceutical laboratories as publicity and the inadequate 
management of medication inventory by the pharmacies and other private or public health establishments. The two possibilities for the destination of unused medication are to be reused or disposed of.

Within this context, the objective of the study aims at discussing the management models of disposing medication waste and the recommendations made by pertinent national and international legislation.

\section{METHODOLOGY}

The study used a descriptive approach of the kind of documental qualitative conducted from June to October 2011. In order to collect data on the structure operates solid waste management of drugs and environmental regulations and major waste medicines adopted the technique of indirect documentation and literature. Technique was used to analyze qualitative data.

The main keywords used were: Dispose of medicines, health risks, environmental contamination and solid waste products, national policy on solid waste, chemical waste.

The main sources were the databases of scientific research, books on the subject, official websites governmental organizations (Nacional Sanitary Surveillance Agency, European Medicines Agency, World Health Organization).

\section{RESULTS AND DISCUSSION}

\section{The international experience with the disposal of medication waste}

Many pharmacies in the US receive expired or unused medication. The cost is estimated at US\$ 2 billion per year, exceeding the current market value of the products. Part of this cost is attributed to the exaggerated consumption of medications (Eickhoff et al., 2009; Daughton, 2003).

The North American regulation agency does not prohibit the reuse of medication and permits each state to have its own regulation. 36 states permit some form of reuse or resale, 17 permit both practices and 12 prohibit both forms (Eickhoff et al., 2009; Daughton, 2003).

There are differences in opinion as to the reuse of medication, because in certain cases, there is no way of knowing the previous storage conditions, such as the temperature and humidity to which they were exposed. As to disposal, in North Carolina the regulations preconize that controlled substances must be discarded by incineration, through the sewage system or taken to a pharmacy to be destroyed (Eickhoff et al., 2009; Daughton, 2003).
There is controversy as to the orientation to dispose of medications by flushing them down the toilet, because it has been verified that the water is contaminated through the sewage system (Eickhoff, et al., 2009; World Helath Organization, 1999b).

Canada is one of the countries that have demonstrated great concern regarding the management of waste. In 1996, the pharmaceutical industries in British Columbia voluntarily established the EnviRX Program with the objective of orienting the consumer. In 1997, the province's government expanded the Post-consumer Residual Stewardship Program Regulation, which had the purpose of accepting all expired over-the-counter and certain prescription medications, and not accepting free samples (Eickhoff et al., 2009)

The British Columbia pharmacies have been part of the Medications Return Program-MRP since 2001. Among the justifications to participate in the program, they mention the reduction of accidental poisoning of children by expired medications, the reduction of costs, improper selfmedication and the potential damage to the environment (Eickhoff et al., 2009; Daughton, 2003).

The Pharmaceutical Association, in the province of Alberta, Canada, has been conducting a survey with consumers about the discarding of pharmaceutical products, personal care and why they are not completely used (Daughton, 2003). Another experiment is a project that involves the triage of prescriptions at public and private pharmacies, where the pharmacist dispenses an initial quantity, and if the medication is tolerated, they dispense the rest of the prescribed medication. This alternative has the objective of avoiding the waste of medications caused by the interruption or change in treatment (Eickhoff et al., 2009).

Europe has a few programs for reverse medication logistics. Italy, France and Spain have presented the largest programs. For certain medical products, the European agency recommends that unused or expired preparations be returned to the pharmacies (Eickhoff et al., 2009; Daughton, 2003).

In Australia, in 1998, a collection program was launched in a partnership between the Government of New South Wales and several pharmaceutical industries (Eickhoff et al., 2009; Daughton, 2003).

\section{International organizations' recommendations}

In 1999, the World Health Organization (WHO) published a recommendation guide on the management of waste generated by health services, which was called the Safe Management of Wastes from Health-care Activities 
TABLE I - Main national and international laws for solid waste of medicinal products

\begin{tabular}{lll}
\hline COUNTRY / AGENCY REGULATORY & LAW & REGULATORY IMPACT \\
\hline BRAZIL/SNVS ${ }^{1}$ & Law No. 6360 of 1976 & $\begin{array}{l}\text { Restructured the norms for the registration and inspection of } \\
\text { medications that required the prescription to be presented for } \\
\text { the sale of medications, with the objective of controlling the } \\
\text { consumption of pharmaceuticals. }\end{array}$ \\
\hline
\end{tabular}

BRAZIL/SNVS $^{1} \quad$ Decree No. 79.094 of 1977

Regulates Law No. 6.360 of September 23, 1976, to submit health monitoring system medicines, pharmaceutical ingredients, drug related, cosmetics, hygiene products, disinfectants and other.

\begin{tabular}{|c|c|c|}
\hline BRAZIL/Presidency of the republic & Federal Constitution of 1988 & $\begin{array}{l}\text { Creation of the Integrated Health System (SUS) and defined } \\
\text { through Law No. 8.080/90. }\end{array}$ \\
\hline BRAZIL/CONAMA ${ }^{2}$ & Resolution No. 006 of 1988 & $\begin{array}{l}\text { There is the inclusion of chemical industries with more than } \\
\text { fifty employees in the "industrial waste control". }\end{array}$ \\
\hline$\overline{\mathrm{BRAZIL} / \mathrm{SNVS}{ }^{1}}$ & Law No. 9.78 of 1999 & $\begin{array}{l}\text { Approved, which created the National Sanitary Surveillance } \\
\text { Agency (ANVISA), a regulatory milestone of the sector. }\end{array}$ \\
\hline$\overline{\text { BRAZIL/ANVISA }^{3}}$ & RDC Resolution No. 306 of 2004 & $\begin{array}{l}\text { Normative instructions for the current waste has adopted its } \\
\text { classification criterion based on environmental legislation. }\end{array}$ \\
\hline$\overline{\text { BRAZIL/CONAMA }^{2}}$ & Resolution No. 358 of 2005 & $\begin{array}{l}\text { Normative instructions for the current waste has adopted its } \\
\text { classification criterion based on environmental legislation. }\end{array}$ \\
\hline$\overline{\mathrm{BRAZIL} / \mathrm{ABNT}^{4}}$ & NBR 10.004 Norm & $\begin{array}{l}\text { Normative instructions for the current waste has adopted its } \\
\text { classification criterion. }\end{array}$ \\
\hline$\overline{\text { BRAZIL/ANVISA }^{3}}$ & Law No. 12.305 of 2010 & $\begin{array}{l}\text { Institutes the National Policy on Solid Waste; change the Law } \\
9605 \text { of February } 12,1998 \text {, and other measures. }\end{array}$ \\
\hline$\overline{\mathrm{BRAZIL} / \mathrm{MMA}^{5}}$ & Ordinance No. 112 of 2011 & $\begin{array}{l}\text { Establishes Working Group for the purpose of articulating, } \\
\text { under federal, the implementation of the National Solid } \\
\text { Waste. }\end{array}$ \\
\hline$\overline{\mathrm{BRAZIL} / \mathrm{MMA}^{5}}$ & Ordinance No. 113 of 2011 & $\begin{array}{l}\text { Approves the Internal Rules of the Steering Committee for } \\
\text { Implementation of Reverse Logistics Systems. }\end{array}$ \\
\hline Geneva/WHO ${ }^{6}$ & Guidelines 1999 a & $\begin{array}{l}\text { Safe disposal of unwanted pharmaceutical in and after } \\
\text { emergencies. }\end{array}$ \\
\hline Geneva/WHO ${ }^{6}$ & Guidelines 1999 b & Safe management of wastes from health-care activities. \\
\hline United States & $\begin{array}{l}\text { Federal solid waste disposal act of } \\
1965 .\end{array}$ & $\begin{array}{l}\text { Established Federal standards and requirements for state and } \\
\text { regional authorities respecting solid waste disposal. }\end{array}$ \\
\hline
\end{tabular}

\begin{tabular}{lll}
\hline Spain & Law N 10 of 1998 & Preparation of national plans for waste and admits the
\end{tabular}
possibility that local authorities can develop their own waste management plans.

\begin{tabular}{lll}
\hline EUROPEAN PARLIAMENT & $\begin{array}{l}\text { Council Directive 75/442/EEC of } \\
\text { 15 July } 1975\end{array}$ & $\begin{array}{l}\text { Having regard to the Treaty establishing the European } \\
\text { Economic Community Community, in particular Articles } 100 \\
\text { and 235, the Council of the European Communities, adopts } \\
\text { measures concerning waste. }\end{array}$ \\
\hline EUROPEAN PARLIAMENT & $\begin{array}{l}\text { Council Directive 2000/76/EC of } 4 \\
\text { December 2000. }\end{array}$ & $\begin{array}{l}\text { Having Regard to The Treaty Establishing the European } \\
\text { Community, and in particular Article 175 (1) thereof, and the } \\
\end{array}$ \\
& $\begin{array}{l}\text { Parlamient The European Council of the European Union, } \\
\text { established on waste incineration. }\end{array}$ \\
\hline
\end{tabular}

${ }^{1}$ SNVS: National Sanitary Surveillance Department; ${ }^{2}$ CONAMA: National Environment Council; ${ }^{3}$ ANVISA: National Sanitary Surveillance Agency; ${ }^{4} \mathrm{ABNT}$ : Brazilian Technical Norms Association; ${ }^{5} \mathrm{MMA}$ : Ministry of the Environment; ${ }^{6} \mathrm{WHO}$ : World Health Organization. 
(World Health Organization, 1999b). In the recommendations on health waste management, medications are mentioned, but without much specificity.

The Guidelines for Safe Disposal of Unwanted Pharmaceutical in and after Emergencies published by WHO (World Health Organization, 1999a) is aimed at the officials of countries with the objective of implementing a policy for the management and final disposal of medications. The disposal methods covered are: return to the industry; disposal in landfills, whenever the residue is encapsulated or deactivated; in landfills with protection to the aquiferous and sewage systems; incineration in closed containers; incineration at medium temperatures; and chemical decomposition. However, according to Daughton (2003), the guide is better indicated for large volumes and emergency situations (Eickhoff et al., 2009).

The WHO clarifies; through the national policy for the safe destination of health service's waste and that the government is responsible for creating the regulations for this waste and ensures that the administrators of health assistance centers assume the responsibility for guaranteeing the correct disposal. And this requires coordination that involves the Health Ministry as well as other ministries.

\section{The Brazilian national environment system}

The National Brazilian System - SISNAMA, is formed by the agencies and entities of the Union, the states, the Federal District, Municipalities and foundations of the various levels of the public authority responsible for the protection and quality of the environment, creating an environmental system management (Milaré, 2005).

SISNAMA has the following structure:

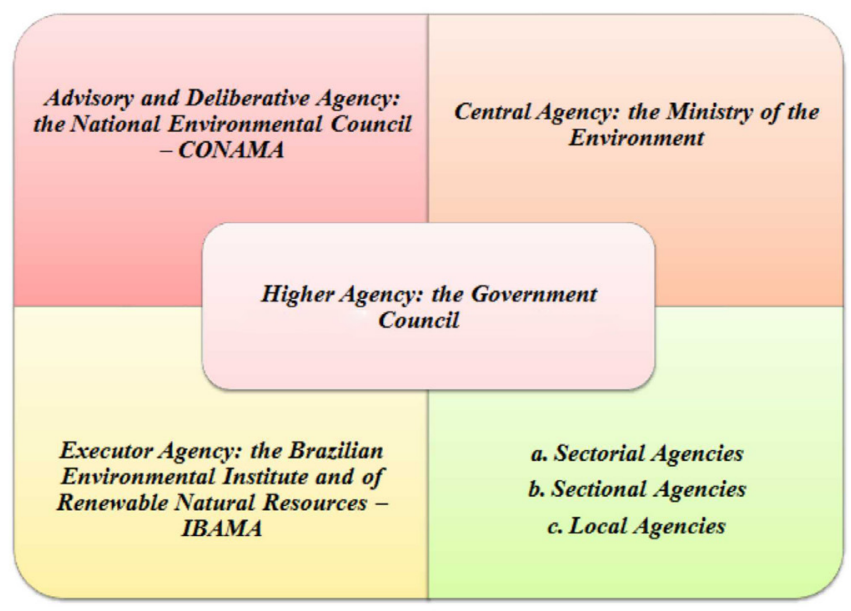

ORGANOGRAM 1 - Graphical representation of the structure of National Brazilian System.

\section{The Brazilian national sanitary surveillance system}

The National Sanitary Surveillance Department (SNVS) was created in 1976; and in 1978, the Medication Division (Dimed) was created as the agency that controls and inspects the pharmaceutical industry in Brazil.

Still in 1976, the Sanitation Surveillance Law (Law No. 6360/1976) was approved, which restructured the norms for the registration and inspection of medications that required the prescription to be presented for the sale of medications, with the objective of controlling the consumption of pharmaceuticals; and afterwards, with decree No. 79.094/77, which regulates Law No. 6360/76.

Another important fact was the creation of the Integrated Health System (SUS), created by the Federal Constitution of 1988 and defined through Law No. 8.080/90, to organize public health actions and services in Brazil. Law No. 9.782/99 was later approved, which created the National Sanitary Surveillance Agency (ANVISA), a regulatory milestone of the sector. ANVISA is an institution that belongs to the sanitary law, which composes the Integrated Health System, and it is responsible for the coordination of the National Sanitary Surveillance System, besides assuming the responsibility for other important programs and a large variety of products and services in order to reduce sanitary risks and make the promotion of the public's health feasible.

\section{Current Brazilian regulations}

In August of 2010, Law No. 12.305 was published, which instituted the National Solid Waste Policy, and regulated in December of the same year by Decree No. 7.404, and creates the National Solid Waste Policy's Inter-ministerial Committee, for the implementation of the Reverse Logistics Systems (Brasil, 2010).

We emphasize that this law does not clarify the issue of medications and/or waste originated from medications. Therefore, there is still no specific legislation in effect in Brazil regarding the final disposal of medications. The issue is approached indirectly by the Ministry of Health and the Ministry of the Environment with technical regulations for the management, treatment and final disposal of health service waste. Within this scope, we currently have the RDC Resolution No. 306, of December 7, 2004 (National Sanitary Surveillance, 2008) and Conama Resolution No. 358, of April 29, 2005 (Ministry of the Environment, 2005).

Within the scope of RDC Resolution No. 17 of 2010 regarding the Good Manufacturing Practices; section I, 
item XVIII states that there must be waste management in the self-inspection reports.

The industrial waste control issue is already dealt with in CONAMA Resolution No. 006 of 1988. Article 1 of the norm requires that industrial waste be the object of specific control, among the examples of types of industries subjected to this control, there is the inclusion of chemical industries with more than fifty employees.

The Pharmaceutical Industry is a considerable generator of solid waste due to the return and collection of medications from the market (distributors, pharmacies, drugstores and hospitals), discarding by quality control and losses inherent to the process (Falqueto et al., 2010).

For the companies that operate in the different stages of medication distribution (manufacturers, distributors, pharmacies, drugstores and hospitals), they must adapt to the sanitary legislation throughout the entire process, in which good transportation and storage practices must be included, as well as legislation referring to the environment, as for example, the National Environment Council (CONAMA) (Falqueto et al., 2010).

The pharmaceutical industries must observe the aforementioned legislation and specific considerations for their environmental licensing, which is a requirement proposed by the National Environment Policy for environmental control. The activity of manufacturing pharmaceutical products is inserted in the chemical industry topic of the list included in Conama Resolution No. 237, of 1997. It is necessary to pay attention to the requirements, because the pharmaceutical industries are also included in Law No. 9.605, de 1998 ("Environmental Crimes Law") through article 56 of the referred law (Pinto et al., 2009; Milaré et al., 2005; Junior et al., 2005).

\section{Current solid waste classification methods}

The normative instructions for the current waste has adopted its classification criterion based on environmental legislation and technical norm documents, especially in CONAMA Resolution No. 358/05, of the National Environment Council, in ABNT NBR 10.004 Norm, of the Brazilian Technical Norms Association, and ANVISA RDC Resolution No. 306/04, of the National Sanitary Surveillance Agency (Falqueto et al., 2010; Pinto et al., 2009).

These norms use the term solid waste, in which waste in solid or semi-solid state are defined that result in activities from the community of origin: industrial, domestic, hospital, commercial, agricultural, services and sweepings (Pinto et al., 2009).

\section{Solid waste classification according to ABNT NBR 10.004}

This norm classifies solid waste as to its potential risks to the environment and public health. The responsibility for radioactive waste belongs to the National Nuclear Energy Committee (CNEN), and therefore, is not included in this norm (Pinto et al., 2009).

The process of waste classification, firstly involves the identification of the process or activity that originated them, their composition and characteristics, as well as the comparison of their composition with the lists of waste and substances whose impact to health and the environment is known. The classification reports can be based on the productive process itself, whenever the classification is included in the ABNT NBR 10.004 list. For this norm, waste is classified as shown in Table II.

\section{Classification of solid waste according to ANVISA RDC No. 306/04 and CONAMA No. 358/05 resolutions}

These resolutions legislate especially in relation to the management, treatment and final disposal of health service waste.

For hazardous medication waste (HMW), according to the technical norm are classified as a subgroup of Group $\mathrm{B}$ (chemicals).

The HMWs can present the possibility of simultaneous classification, for example, a radioactive biological material.

\section{Waste treatment and destination}

Waste must be segregated, and each type of waste must be given a different treatment. Thus, before segregating it, its final destination must be known. "Waste treatment is the application of a method, technique or process that changes the waste's characteristics, reducing or eliminating the risk of contamination, work-related accidents or damage to the environment" (Brasil, 2004).

The final disposal of waste must meet construction and operation technical criteria that require environmental licensing according to CONAMA Resolution No. 237/97 (Brasil, 1997b). Currently, the most common forms of final disposal of waste being used are:

Sanitary landfill: Technique for the final disposal of urban solid waste in the soil, by means of confinement in layers covered with inert material, according to specific norms, so as to avoid damage or risk to public health and 
TABLE II - Classification of waste

\begin{tabular}{lll}
\hline Class & Classification & Description \\
\hline Class I & Hazardous & $\begin{array}{l}\text { Waste, which because of their physical, chemical or infecto-contagious properties, may } \\
\text { present risks to public health. For example: products with flammable, corrosive, reactivity, } \\
\text { toxicity and pathogenicity characteristics. }\end{array}$ \\
\hline Class II & Non-hazardous & The non-hazardous waste was listed in the ABNT NBR 10.004. \\
\hline Class II A & Non-inert & Those who do not fit the classifications of Class I waste - Hazardous waste or class II \\
& B - inert. The residue class II - not inert may have properties such as biodegradability, \\
& combustibility or water solubility. \\
\hline Class II B & Inert & $\begin{array}{l}\text { Any residues that, when sampled in a representative and subjected to a dynamic and } \\
\text { static contact with distilled or deionized water at room temperature, do not have any of } \\
\text { its constituents dissolved concentrations exceed the standards of potable water, except } \\
\text { for appearance, color, haze, hardness and flavor. }\end{array}$ \\
\hline
\end{tabular}

TABLE III - Classification of waste in accordance with CONAMA resolutions No. 358 and ANVISA RDC 306

\begin{tabular}{ll}
\hline Group A & Waste with the possible presence of biological agents. This group is subdivided into 5 classes: A1, A2, A3, \\
A4 and A5. & Waste containing chemical substances with flammable, corrosive, reactive and toxic characteristics. \\
Group B & Material resulting from human activities that contain radionuclides in quantities greater than the limits. \\
Group C & Waste that does not present risk, for example, domestic waste. \\
Group D & $\begin{array}{l}\text { Puncturing, cutting or scarifying materials, for example: needles, scalpel blades, lancets, micro-pipettes, } \\
\text { pipettes, Petri dishes) }\end{array}$ \\
\hline
\end{tabular}

TABLE IV - Classification of the types hazardous medication waste

\begin{tabular}{ll}
\hline Type 1 & Hazardous medication that wasn't used, was partially used, is expired or cannot be used \\
& Hazardous medication originating from spills, as well as containment, absorption, removal and cleaning \\
material contaminated by them & HEPA filters from safety cabins where hazardous medication is handled \\
& Infusion pockets and equipment, filled or partially used, and other non-empty containers containing solutions \\
& of hazardous medications over the established limits \\
\hline Type 2 & Empty containers, including primary packages, when they are completely empty (for example: bottles, vials, \\
& pill blisters) and equipment, utensils or disposable devices \\
& Personal Protective Equipment originating from the handling and preparation of hazardous medications and \\
& routine activities \\
& Surface, workbench and safety cabin liners that had no direct contact with hazardous medications
\end{tabular}

guarantee safety, minimizing environmental impacts (Pinto et al., 2009).

Class I Hazardous Waste Landfill: Technique for the disposal of chemical waste in the soil, using specific engineering procedures for its confinement, without causing damage or risk to public health and reducing environmental impact (Pinto et al., 2009).

The sanitary landfill norms are dealt with especially by ABNT NBR norm No. 13.896, of July 30 of 1997 , which deals with Non-hazardous waste landfills - Criteria for the project, implementation and operation; CONAMA RESOLUTION No. 313, of October 29, 2002 / ANNEX III, which Regulates the national industrial solid waste inventory; ABNT NBR 8418 and NBR 842 Abridgement on the Presentation of hazardous industrial waste landfill projects and ABNT NBR 1057 and NBR 1025 Abridgement on the Hazardous waste landfills - Criteria for the project, construction and operation.

Co-processing: is the thermal destruction of waste in cement kilns. Its difference in relation to other burning 
techniques lies in the use of the waste as alternative fuel (for its energy potential), and as a raw material replacement in the cement industry. In order to obtain a uniform feed in the cement kilns, the waste must be blended.

Co-processing is dealt with in Conama Resolution No. 264, of August 26 of 1999, which defines specific environmental licensing procedures, criteria and technical aspects for the co-processing of waste in revolving clinker kilns for the manufacturing of cement.

Incineration: Is the destruction process via thermal oxidation performed in high temperatures, widely used for the treatment of hazardous waste (as for example: persistent, toxic and flammable organic products). This process generates scoria and ash, which require final destination later (Pinto et al., 2009).

Regarding incineration, we have CONAMA RESOLUTION No. 6, of September 19 of 1991, which Regulates the incineration of solid waste originating from health establishments, ports and airports; CONAMA RESOLUTION No. 316, of October 29 of 2002, which Regulates procedures and criteria for the operation of waste thermal treatment systems; and ABNT NBR 11175, of August 30 of 1990, which deals with Incineration of hazardous solid waste - Performance standards - Procedure

\section{Pharmaceuticals in water treatment stations}

"Residual pharmaceuticals present in domestic sewage and natural water is an issue that is being discussed internationally. Studies demonstrate that these pharmaceuticals and their metabolites are present worldwide, such as Germany, Brazil, Canada, Holland, England, Italy, Sweden, the United States and the United Kingdom" (Bila et al., 2003).

Pharmaceuticals are normally absorbed by the body and are subject to metabolic reactions. However, a significant quantity of these substances and their possible metabolites are eliminated through urine, feces or manure, being frequently found in domestic sewage. Studies report that in general, 40 to $90 \%$ of the administered dose is excreted in its original form (Bila et al., 2003).

Once it is in the environment, the destination of pharmaceuticals depends on their structural characteristics and physical-chemical properties, such as photosensitivity, biodegradability and lipophilicity. Certain pharmaceuticals, such as acetylsalicylic acid and caffeine, are biodegradable and therefore, are efficiently removed at Sewage Treatment Stations (STS), reaching removal rates of $99.99 \%$. Penicillin is also hardly found in the environ- ment, due to the chemical imbalance of its $\beta$-lactamase ring (Bila et al., 2003).

Synthetic estrogens and tetracycline antibiotics tend to be absorbed by STS Iodine and /or sediments, due to their high lipophilicity and the precipitated forming of calcium and ions respectively similar (Castiglioni et al., 2006).

It is important to emphasize that in Brazil there is a greater incidence of pharmaceuticals in residual water due to the lack of sewage treatment in the country.

\section{Conventional effluent treatment methods}

There are currently several treatment methods that are being used, such as: coagulation, flocculation, sedimentation, filtration, ionic exchange processes, adsorption with activated carbon, membrane separation, biodegradation, electro-chemical processes and photo-degradation (Melo et al., 2009; Bila et al., 2003).

Biological processes are more frequently used because they allow the treatment of large volumes and can reach a higher rate of organic matter removal at relatively low cost (Bila et al.,2003; Castiglioni et al., 2006; Bila et al., 2003).

In pharmaceutical biodegradation studies, the removal rates were of $50 \%$ for conventional activated iodine systems (Melo et al., 2009; Bila et al., 2003).

Decantation, flotation, filtration and adsorption are processes characterized by the transfer of the contaminant phase and degradation does not necessarily occur. However, they are efficient and can be useful as pre or post-treatment of the final process. In Sewage Treatment Stations (STS), which operate with active iodine systems, the adsorption is the main mechanism for the removal of lipophilic pharmaceuticals, such as estrogens (Melo et al., 2009; Bila et al., 2003).

The efficiency of pharmaceutical removal in STSs depends on the physical-chemical properties of each compound. For example, for carbamazepine, an anticonvulsant, a removal of $7 \%$ was observed, while acetylsalicylic acid had a removal rate of $99 \%$ in a STS in Germany. This oscillation in the rate of removal was also observed in a STS in Finland, where 26\% of removal was obtained for Diclofenac and $92 \%$ for Ibuprofen. Polar compounds tend to remain in their aqueous phase, which favors their infiltration into the aquatic environment. On the other hand, non-polar compounds are removed by adsorption in iodine (Melo et al., 2009; Bila et al., 2003).

\section{Advanced oxidative processes for the degradation of residual pharmaceuticals}

The advanced oxidative processes (AOP) are pre- 
sented as alternatives or supplements to the traditional treatment processes of effluents, because the hydroxyl radicals that are generated are very reactive and not selective, and act in an interesting manner in the chemical oxidation of several substances (Huber et al., 2003).

These radicals may react with organic contaminants through distinct mechanisms, depending on the molecular structure. Examples of oxidative processes: hydrogen peroxide photolysis, ozonation, heterogeneous photocatalysis, Fenton and photo-Fenton (Klavarioti et al., 2009).

"AOP degradation of pharmaceuticals, as well as direct photolysis (which depends on each compound's absorbance), involves different stages and various reactions that result in different sub-products, which may present greater or less toxicity in comparison to the original pharmaceutical." (Melo et al., 2009).

These intermediaries may maintain, or not, the functional activity of the original compound. In studies, the toxicity and biodegradability of the intermediaries of a sulfamethoxazole antibiotic solution $(200 \mathrm{mg} / \mathrm{L})$ were evaluated after the application of the photo-Fenton process. Through the results of the $\mathrm{DBO} / \mathrm{DQO}$ ratio, it was observed that by increasing the dose of $\mathrm{H}_{2} \mathrm{O}_{2}$ from 50 to $550 \mathrm{mg} / \mathrm{L}$ during the treatment, there was an increase in biodegradability. Other reported relevant information was that for a lower dose of $\mathrm{H}_{2} \mathrm{O}_{2}(50 \mathrm{mg} / \mathrm{L})$ being used, there was an increase in the solution's toxicity, which indicates that in this condition, intermediaries that were more toxic than the original pharmaceutical. However, this was not observed when using greater concentrations of $\mathrm{H}_{2} \mathrm{O}_{2}$, which suggested that the intermediaries being formed may be different depending on the experimental conditions, or that these compounds are quickly degraded (Balcioglu et al., 2003; Melo et al., 2009).

The degradation of sulfamethoxazole was also evaluated by heterogeneous photo-catalysis. It was observed that the COT removal efficiency varied due to the $\mathrm{pH}$. The factor indicated as being responsible for this variation was the difference in degradation routes, which lead to the formation of compounds that do not contain the benzene ring or the isoxazole ring. The DBO/DQO ratio demonstrated the increase in biodegradability of the sulfamethoxazole solution after the application of the heterogeneous photocatalysis, thus emphasizing the applicability of this treatment (Balcioglu et al., 2003; Andreozzi et al., 2004).

Studies have demonstrated that the $\mathrm{DBO} / \mathrm{DQO}$ ratio demonstrated the increase in biodegradability of the sulfometoxazol solution after the application of the heterogeneous photo-catalysis, thus emphasizing the applicability of this treatment (Andreozzi et al., 2004; Melo et al., 2009).

The optimization of the treatment processes is es- sential in order to guarantee the complete mineralization of the target-compounds, reducing the formation of toxic intermediaries. Thus, the development of sensitive analytical methods is necessary in order to identify possible intermediaries and reliable toxicity tests to prevent the impact of these substances to the environment (Castiglioni et al., 2006; Melo et al., 2009).

There is still little information regarding the characteristics of degradation products formed from pharmaceuticals excreted after being treated, this information is fundamental to ensure the effectiveness and safety of the application of such effluent treatment processes containing pharmaceutical waste (Melo et al., 2009).

\section{Analytical methods used in the identification of pharmaceuticals}

For STS effluents, the analysis of residual pharmaceuticals in rivers, subsoil and potable water, requires the development of more sensitive analytical methods for the detection of concentrations with the $\mu \mathrm{g} / \mathrm{L}$ and $\mathrm{ng} / \mathrm{L}$ range, than those performed in biological samples such as blood, urine and others (Bila et al., 2003).

There is a growing concern with the presence of pharmaceuticals in aquatic environments, the monitoring of the removal efficiency of these pharmaceuticals through conventional domestic effluent treatment by the STSs is of great importance, because in the future, there will be the need to adapt, or even implement supplementary processes for the proper removal of such pharmaceuticals (Bila et al., 2003).

\section{The public's awareness of the problem}

A study conducted at the Campinas State University -UNICAMP approached the public's knowledge regarding the problems caused by the domestic disposal of medications, by means of a questionnaire. The survey was based on the environment at the university's campus at 4 collections points and presented a sample of 141 people (Ueda et al., 2009.)

Through an analysis of the data presented, it was verified that it is not only important to promote the implementation of collection policies, because only a restricted part of the public is aware of the problem (Ueda et al., 2009.)

\section{CONCLUSION}

In general, Brazil already has regulations regarding waste management, it is necessary to supplement and update with the existing norms and legislation. 
Health professionals who work directly in healthcare and pharmaceutical industries, practice and have the knowledge about the environmental management policies. The big discussion is how to enable a proper reverse logistics of medicines and which will be responsible on this direct operational management taking into consideration socio-economic diversity and the large extension of Brazilian territory.

ANVISA has already initiated studies about the disposal of medication waste, as well as the revision process of the current RDC No. 306/04 resolution. The state of São Paulo has a more current regulation, Administrative Rule CVS No. 21 of September 19 of 2008 (São Paulo, 2008), which deals, in a peculiar manner, with the classification of hazardous medication waste and takes international references about the issue into consideration. State and international experiences can help to supplement current federal legislation.

The guidance and monitoring of the habits of the population is part of the construction of an organized policy on the proper storage and disposal of residential medicines (Alvarenga et al., 2010)

Plans based on environmental education and in public policies, in the manufacturing process as well as in the amount of medication prescribed, must be discussed with the various sectors of society, in order to minimize the generation of waste. Additionally, there must be incentives for the development of technological research that make lower costs, environmental impact viable and that provide an improvement in the public's quality of life.

The importance of the participation of society, governmental agencies and the entire productive chain is fundamental, because they participate directly as protagonists in this context.

We can conclude that there is the need for a medication waste disposal management program aiming at correct handling procedures and the definition of the responsibilities in the various actions, in order to reduce possible sanitary risks for public health.

\section{REFERENCES}

ALVARENGA, L.S.V; NICOLETTI, M.A. Domestic discarding of medicines and some considerations about the current environment impact. Rev. Saúde, v.4, n.3, p.34-39, 2010 .
ANDREOZZI, R; CAMPANELLA, L; FRAYSSE, B; GARRIC, J; GONELLA, A; GIUDICE R. Lo; MAROTTA, R; PINTO, G; POLLIO, A. Effects of advanced oxidation processes (AOPs) on the toxicity of a mixture of pharmaceuticals. Wat. Sc. Tech., v.50, n.5, p.23-28, 2004.

ASSOCIAÇÃO BRASILEIRA DE NORMAS TÉCNICAS. NBR 10004: Classificação de resíduos sólidos. Rio de Janeiro: ABNT, p.77, 2004.

AZEREDO, F.S.; GUIMARÃES, R.I.; PAULA, J.R.; CUNHA, L.C. Validação de técnica analítica em cromatografia em camada delgada comparativa para identificação de fármacos anorexígenos sintéticos em produtos fitoterápicos. Rev. Eletrôn. Farm., n.1, p.17-24, 2004.

BALCIOGLU, I. A; OTKER, M. Treatment of pharmaceutical wastewater containing antibiotics by $\mathrm{O}_{3}$ and $\mathrm{O}_{3} / \mathrm{H}_{2} \mathrm{O}_{2}$ processes. Chem., v.50, n.1, p.85-95, 2003.

BILA, D.M., DEZZOTI, M.; Fármacos no meio ambiente. Quim. Nova, v.26, n.4, p.523-530, 2003.

BRASIL. AGÊNCIA NACIONAL DE VIGILÂNCIA SANITÁRIA (ANVISA). Descarte de Medicamentos. Available at: <http://189.28.128.179:8080/ descartemedicamentos/apresentacao $>$ Accessed on: 9 Jun. 2011.

BRASIL. AGÊNCIA NACIONAL DE VIGILÂNCIA SANITÁRIA. Resolução RDC nº 306, de 07 de dezembro de 2004. Dispõe sobre o Regulamento Técnico para o gerenciamento de resíduos de serviços de saúde. Diário Oficial da República Federativa do Brasil, Brasília, DF, dez. 2004. Seção 1, n.237, p.49.

BRASIL. CONSELHO NACIONAL DO MEIO AMBIENTE. Resolução CONAMAn ${ }^{\circ} 358$, de 29 de abril de 2005. Dispõe sobre o tratamento e a disposição final dos resíduos dos serviços de saúde e dá outras providências. Diário Oficial da República Federativa do Brasil, Brasília, DF, dez. 2005. Seção 1, n.84, p.63.

BUENO, C.S.; WEBER, D; OLIVEIRA, K.R. Pharmacy home and disposal of medicines in the district of the city of Luiz Fogliatto Ijuí - RS. Rev. Ciênc. Farm. Básica Apl., v.30, n.2, p.75-82, 2009. 
CASTIGLIONI, S; BAGNATI, R; FANELLI, R; POMATI, F; CALAMARI, D; ZUCCATO, E. Removal of pharmaceuticals in sewage treatment plants in Italy. Env. Sc. Tech., v.40, n.1, p.357-363, 2006.

DAUGHTON, C.G. Cradle-to-cradle stewardship of drugs for minimizing their environmental disposition while reduction, and future directions. Environ. Health Perspect., v.111, n.5, p.775-785, 2003.

EICKHOFF, P; HEINECK, I.; SEIXAS, L.J.; Gerenciamento e destinação final de medicamentos: uma discussão sobre o problema. Re. Bras. Farm., v.90, n.1, p.64-68, 2009.

FALQUETO, E.; KLIGERMAN, D.C.; ASSUMPÇÃO, R.F. Como realizar o correto descarte de resíduos de medicamentos? Ciênc. Saúde Coletiva, v.15, supl.2, p.32833293, 2010 .

HUBER, M. M; CANONICA, S; PARK, G. Y; GUNTEN, U. $\mathrm{V}$; Oxidation of pharmaceuticals during ozonation and advanced oxidation processes. Env. Sc. Tech., v.37, n.5, p.1016-1024, 2003.

JUNIOR, A.P.; ALVES, A.C. Curso interdisciplinar de direito ambiental. Barueri: Manoeli, 2005. 965 p.

KLAVARIOTI, M; MANTZAVINOS, D; KASSINOS, D. Removal of residual pharmaceuticals from aqueous systems by advanced oxidation processes. Env. Sc. Tech., v.35, n.2, p.402-417, 2009.

MACHADO, N.L.; MORAES, L.R.S. RSSS: Revisitando as soluções adotadas no Brasil para tratamento e destino final. Eng. San. Amb., v.9, n.1, p.55-64, 2004.

MANNARINO, C.F.; FERREIRA, J.A.; MOREIRA, J.C.; Tratamento combinado de lixiviado de aterros de resíduos sólidos urbanos e esgoto doméstico como alternativa para a solução de um grave problema ambiental e de saúde pública - revisão bibliográfica. Cad. Saúde Colet., v.19, n.1, p.11-19, 2011.

MAZZER, C.; CAVALCANTI, O.A.; Introdução à gestão ambiental de resíduos. Infarma., v.16, n.11, p.67-77, 2004.

MELO, S.A.S; TOVÓ, A.G.; BAUTITZ, I.R; NOGUEIRA, R.F.P. Degradação de fármacos residuais por processos oxidativos avançados. Quím. Nova, v.32, n.1, p.188-197, 2009.
MILARÉ, E. Direito do Ambiente; São Paulo: Revista dos Tribunais Ltda, 2011. 1648 p.

PASCHOAL, J.A.R.; RATH, S.; AIROLDI, F.P.S.; REYES, F.G.R. Validation of chromatographic methods for the determination of veterinary drug residues in food. Quim. Nova, v.31, n.5, p.1190-1198, 2008.

PATERSON, J.M.; ANDERSON, G.M. Trial prescriptions to reduce drug wastage: results from Canadian Programs and a Community Demonstration Project. Am. J. Manag. Care, v.8, n.2, p.151-158, 2002.

PINTO, T.J.A.; VITOLO, M.; FILHO, A.T.; MADERGAN, Y.M.L. Sistema de gestão ambiental. Rio de Janeiro: Guanabara Koogan, 2009. 354 p.

SÃO PAULO (Estado). Centro de Vigilância Sanitária, da Coordenadoria de Controle de Doenças da Secretaria de Estado da Saúde. Portaria CVS no 21 de 10 de setembro de 2008. Norma Técnica sobre Gerenciamento de Resíduos Perigosos de Medicamentos em Serviços de Saúde, Diário Oficial do Estado de São Paulo, 11 Set. 2008. n.171, p.25.

UEDA, J; TARVENARO, R; MAROSTEGA, V; PAVAN, W; Impacto ambiental do descarte de fármacos e estudo da conscientização da população a respeito do problema. Rev. Ciênc. Amb. on-line, v.5, n.1, p.1-5, 2009.

WORLD HEALTH ORGANIZATION (WHO). Safe management of wastes from health-care activities. Geneva: 1999b. Available at : <http:// www.who.int/ water_sanitation_health/medicalwaste/wastemanag/en/>. Accessed on: 8 Jun. 2011.

WORLD HEALTH ORGANIZATION (WHO). Guidelines for safe disposal of unwanted pharmaceutical in and after emergencies. Geneva; 1999a. Available at: < http:// www.who.int/water_sanitation_health/medicalwaste/ unwantpharm.pdf $>$. Accessed on: 9 Jun. 2011.

ZUCCATO, E.; CASTIGLIONI, S; FANELLI, R; REITANO, G; BAGNATI, R; CHIABRANDO, C.; POMATI, F; ROSSETTI, C; CALAMARI, D. Pharmaceuticals in the environment in Italy: causes, occurrence, effects and control. Environ. Sci. Pollut. Res. Int., v.13, n.1, p.15-21, 2006.

ZUCCATO, E.; CALAMARI, D.; NATANGELO, M.; FANELLI, R. Presence of therapeutic drugs in the environment. Lancet, v.355, n.9217, p.1789-1790, 2000. 
ZUCCATO, E.; CASTIOGLIONI, S.; FANELLI, R. Identification of the pharmaceuticals for human use contaminating the Italian aquatic environment. J. Hazard. Mater., v.122, n.3, p.205-209, 2005.
Received for publication on $06^{\text {th }}$ December 2011 Accepted for publication on $10^{\text {th }}$ May 2012 


\section{v.48, n.3, 2012}

- Page 513

Change the duplicated TABLE II for TABLE III as follow bellow or change the following reformulated page.

TABLE III - Classification of waste in accordance with CONAMA resolutions No. 358 and ANVISA RDC 306

Group A

Group B

Group C

Group D

Group E
Waste with the possible presence of biological agents. This group is subdivided into 5 classes: A1, A2, A3, A4 and A5.

Waste containing chemical substances with flammable, corrosive, reactive and toxic characteristics.

Material resulting from human activities that contain radionuclides in quantities greater than the limits.

Waste that does not present risk, for example, domestic waste.

Puncturing, cutting or scarifying materials, for example: needles, scalpel blades, lancets, micro-pipettes, pipettes, Petri dishes) 
TABLE II - Classification of waste

\begin{tabular}{lll}
\hline Class & Classification & Description \\
\hline Class I & Hazardous & $\begin{array}{l}\text { Waste, which because of their physical, chemical or infecto-contagious properties, may } \\
\text { present risks to public health. For example: products with flammable, corrosive, reactivity, } \\
\text { toxicity and pathogenicity characteristics. }\end{array}$ \\
\hline Class II & Non-hazardous & The non-hazardous waste was listed in the ABNT NBR 10.004. \\
\hline Class II A & Non-inert & $\begin{array}{l}\text { Those who do not fit the classifications of Class I waste - Hazardous waste or class II } \\
\text { B - inert. The residue class II - not inert may have properties such as biodegradability, } \\
\end{array}$ \\
& combustibility or water solubility. \\
\hline Class II B & Inert & $\begin{array}{l}\text { Any residues that, when sampled in a representative and subjected to a dynamic and } \\
\text { static contact with distilled or deionized water at room temperature, do not have any of } \\
\text { its constituents dissolved concentrations exceed the standards of potable water, except } \\
\text { for appearance, color, haze, hardness and flavor. }\end{array}$ \\
& &
\end{tabular}

TABLE III - Classification of waste in accordance with CONAMA resolutions No. 358 and ANVISA RDC 306

\begin{tabular}{ll}
\hline Group A & Waste with the possible presence of biological agents. This group is subdivided into 5 classes: A1, A2, A3, \\
A4 and A5. & Waste containing chemical substances with flammable, corrosive, reactive and toxic characteristics. \\
Group B & Material resulting from human activities that contain radionuclides in quantities greater than the limits. \\
Group D & Waste that does not present risk, for example, domestic waste. \\
Group E & $\begin{array}{l}\text { Puncturing, cutting or scarifying materials, for example: needles, scalpel blades, lancets, micro-pipettes, } \\
\text { pipettes, Petri dishes) }\end{array}$ \\
\hline
\end{tabular}

TABLE IV - Classification of the types hazardous medication waste

\begin{tabular}{ll}
\hline Type 1 & Hazardous medication that wasn't used, was partially used, is expired or cannot be used \\
& Hazardous medication originating from spills, as well as containment, absorption, removal and cleaning \\
& material contaminated by them \\
& HEPA filters from safety cabins where hazardous medication is handled \\
& Infusion pockets and equipment, filled or partially used, and other non-empty containers containing solutions \\
& of hazardous medications over the established limits \\
\hline Type 2 & Empty containers, including primary packages, when they are completely empty (for example: bottles, vials, \\
& pill blisters) and equipment, utensils or disposable devices \\
& Personal Protective Equipment originating from the handling and preparation of hazardous medications and \\
& routine activities \\
& Surface, workbench and safety cabin liners that had no direct contact with hazardous medications
\end{tabular}

guarantee safety, minimizing environmental impacts (Pinto et al., 2009).

Class I Hazardous Waste Landfill: Technique for the disposal of chemical waste in the soil, using specific engineering procedures for its confinement, without causing damage or risk to public health and reducing environmental impact (Pinto et al., 2009).

The sanitary landfill norms are dealt with especially by ABNT NBR norm No. 13.896, of July 30 of 1997 , which deals with Non-hazardous waste landfills - Criteria for the project, implementation and operation; CONAMA RESOLUTION No. 313, of October 29, 2002 / ANNEX III, which Regulates the national industrial solid waste inventory; ABNT NBR 8418 and NBR 842 Abridgement on the Presentation of hazardous industrial waste landfill projects and ABNT NBR 1057 and NBR 1025 Abridgement on the Hazardous waste landfills - Criteria for the project, construction and operation.

Co-processing: is the thermal destruction of waste in cement kilns. Its difference in relation to other burning 